\title{
Paleoecology of a Late Pleistocene Small Mammal Community from Interior Alaska
}

\author{
R. D. GUTHRIE ${ }^{1}$
}

\begin{abstract}
Fossil small mammals from late Pleistocene sediments in interior Alaska were used to investigate the paleoecology of the region. The predominant member of the fossil assemblage was Microtus gregalis indicating that the area was above tree line and occupied by a fauna and flora which preferred well-drained soils. Three species were found as fossils which are not in the area today: Microtus gregalis, Citellus undulatus, and Dicrostonyx torquatus. Their extinction in interior Alaska appears to be due to a rapid reduction of their preferred habitat at the end of the Wisconsin glaciation. The ecological interpretation of the paleocommunity and its extinction is consistent with interpretations from fossil large mammal assemblages from the same area.
\end{abstract}

RÉSUMÉ. Paléoécologie d'un Petit Groupe de Mammifères du Pléistocène Récent de l'Intérieur de l'Alaska. De petits mammifères fossiles des sédiments du Pléistocène récent de l'Alaska intérieur ont servi à l'étude de la paléoécologie de cette région. L'élément dominant de cet assemblage fossile était Microtus gregalis, ce qui indiquerait que la région se trouvait au nord de la limite de la zone forestière et que la faune et la flore qui l'occupaient préféraient les sols bien drainés. Trois espèces fossiles sont maintenant absentes de la région: Microtus gregalis, Citellus undulatus et Dicrostonyx torquatus. Leur extinction dans l'Alaska intérieur semble due à une régression rapide de leur habitat préféré, vers la fin de la glaciation wisconsinienne. Cette interprétation écologique du paléogroupe et de son extinction concorde avec les interprétations que suggèrent les assemblages fossiles de grands mammifères de la même région.

РЕЗЮМЕ. Палеоколоаия позднеплейсточенового сообщества мелких млекопитаюирих во внутренних районах Аляски. Палеоэкология внутренних ранонов Аляски была изучена на основе мелких ископаемых млекопитающих из позднеплейстоденовых отложений. Преобладание Microtus gregalis среди ископаемых позволяет высказать предположение, что исследованные районы находились выше границы леса и являлись областью распространения фауны и флоры, предпочитающих хорошо дренированные почвы. Среди ископаемых было найдено три вида: Microtus gregalis, Citellus undulatus и Dicrostonyx torquatus, не встречающиеся в данной области в настоящее время. Их исчезновение было, очевидно, связано с сокращением их ареала в конце Висконсинского оледенения. Экологическая интерпретация ископаемого сообщества и факт его исчезновения хорошо согласуются с данными, полученньми при изучении сообществ крупных ископаемых млекопитающих в әтих же районах.

\section{INTRODUCTION}

Many of the Nearctic mammalian species represent, or have evolved from, late Tertiary and Pleistocene immigrants from Eurasia. Therefore, an understanding of the mammalian paleoecology of the Beringian Refugium (Eastern Siberia and Alaska) is necessary to interpret intercontinental community relationships, and

\footnotetext{
1Department of Biological Sciences, University of Alaska, College, Alaska.
} 
the chronology of these interchanges. Unfortunately there are some major limitations, since no pre-Pleistocene terrestrial vertebrate fossils have been found in Alaska; moreover, virtually all of the non-marine sediments containing vertebrates are of late Pleistocene age (Péwé et al., 1965).

Although there have been many tens of thousands of fossil large mammal elements recovered from these late Pleistocene sediments, only a few small mammal fossils have been collected. This is easy to understand because special techniques are required to find fossil small mammals, whereas the elements of large species are conspicuous in the fresh exposure. A series of small mammal fossils, as yet undescribed, was collected from the Fairbanks area by the late O. W. Geist of the University of Alaska. These are deposited in the Frick Collection at the American Museum of Natural History, New York. Péwé (1957) was first to compile a generic list of the fossil small mammals from Alaska, mostly from Geist's collections. Repenning et al. (1964) described a fauna of small fossil mammals from the Tofty Mining District about $160 \mathrm{~km}$. west of Fairbanks. Their samples were taken from bone concentrations which they think represent a mixing of recent and fossil species resulting from extensive erosion and redeposition since the Wisconsin glaciation.

Most of the large mammal fossils collected from Alaska during the gold mining boom had no accompanying stratigraphic information, primarily because the miner's hydraulic "gun" knocks most of the bones out of the exposure before they can be seen and their position recorded. On the other hand, the techniques required to collect fossil small mammals depend on localized sampling of physically distinct and partially datable stratigraphic units. While one must therefore work with the large mammal assemblage collectively using only general chronological information from the entire exposure (Guthrie 1968), the small mammal assemblage can be studied in detailed stratigraphic profiles.

Unlike large mammals, which have large home ranges covering various types of habitats, the home ranges of individual small mammals tend to be more restricted. Although there are some exceptions, small mammals are more subject to local microhabitat limitations than large mammals, and consequently they are more sensitive indicators of environment. This point has been made numerous times by many different authors. There are, however, some depositional and recovery biases that apply more to small than to large mammal species. Small mammal remains are much more subject to long distance transport by either physical or biotic forces. Mouse bones, for example, are quite buoyant in rapidly moving water and may be carried for miles from their point of origin. Predatory birds and mammals sometimes have large home ranges that include several types of habitat. A mouse caught in the woodlands could be dropped as faeces in an open meadow. Because of their small size, the bones of small mammals would be less resistant to destruction by exposure and crushing than large mammal bones, but might be more easily covered by sediment and preserved.

There are also some behavioural biases that influence the fossil small mammal assemblage. Many localized concentrations of small mammal remains are a product of predator middens. We know that predators do not sample the available prey species at random. For example, owls would be much more inclined to 
take nocturnal mice while hawks would be more likely to catch diurnal mice. Small mice which prefer habitats with overhead cover will probably have a different type of predation than larger mice that occur in more open habitats.

There have been numerous references to paleosynecology in studies of fossil small mammal assemblages. Hibbard et al. (1965) review many of these studies from North America. Most of these involve the use of fossil mammals in reconstructions of vegetational or climatic shifts during glacial or interglacial stages. Several authors have repeatedly stressed the stratigraphic value of small mammals, particularly microtines, both because of their rapid evolution and their universal occurrence in the Holarctic. Much more collecting of fossil small mammals has taken place in Europe than anywhere else in the world, and correspondingly more is known about European fossil communities. Kurtén (1960) and Kowalski (1966) have published the most recent reviews of the chronology and faunal evolution of European small mammals. Slowly, collections of fossil small mammals are accumulating elsewhere in the Holarctic, and stratigraphic correlations and comparisons of evolutionary patterns are being made. Although this study does not illustrate any dramatic intraspecific evolutionary changes, because of the short time span represented by the units that were sampled, it does deal with the paleoecological implications of the distributional history of living species and sets the stage for future comparisons with early and middle Pleistocene species.

\section{STRATIGRAPHY AND DESCRIPTION OF COLLECTING SITES}

It has not been my intent to undertake a basic stratigraphic study of the YukonTanana upland, but only to record the stratigraphic relationships of the samples and to note features which may pertain to the ecology of the fossil vertebrates. The Pleistocene geomorphology and stratigraphy of the Fairbanks area have been studied by Péwé (e.g., 1955, 1957, 1965). His overall interpretations of the chronology and origin of the sediments are consistent with the findings of this study. With some modifications, Pewe's interpretations of the sediments in the Fairbanks area probably apply generally to the entire Yukon-Tanana upland, particularly the southern half. Repenning et al. (1964) reviewed the most salient features of the area's geography and geology. The Yukon-Tanana upland is enclosed by the discrete boundaries of the Yukon and Tanana flood plains, to the north and south respectively. It is approximately $99,000 \mathrm{~km} .^{2}$ in area and ranges up to about $2,000 \mathrm{~m}$. in altitude. The unconsolidated silt sediments represent with rare exceptions only the late Pleistocene, from early Illinoian time to the present (Péwé et al. 1965).

Most of the deposition occurred during the glacial stages, when aggradation of trunk streams due to glaciation in the Alaska Range created large unvegetated flood plains that served as a source for aeolian silt (Péwé et al. 1965). As yet there are no units in the Fairbanks area which have been assigned to interglacials or interstadials, although some deposits may consist of reworked sediments and fossils of both glacial and interglacial age (Matthews 1968).

Most of the exposures are the result of mining "cuts" through the silt overburden to reach the auriferous gravels. Very few cuts are still actively mined, 
but most mines have not been abandoned very long and the silt walls still remain unvegetated. The most striking feature of freshly exposed sections is the difference in colour between the different units. Those designated by Péwé as Wisconsin are dark grayish-brown whereas the Illinoian sediments commonly have a greenish cast. There are, however, some minor exceptions to this colour delimitation. The miner's jet of water, which is used to wash the daily thaw increment from the frozen face of the exposure, removes some beds faster than others. The more peaty layers are more resistant than less organic zones. This wash-thaw-wash-thaw process creates a bench or series of benches in which the cap of each is composed of resistant peat. The ice content of the frozen silt also plays an important role in the rate of silt removal. The upper part of the Wisconsin zone, which usually contains wedge ice masses, erodes more rapidly than any other part of the section.

During this study the muck was removed into hand buckets and transported to the washing site where it was then screen-washed through 40 mesh (40 per inch) screens. Over 4,000 buckets of silt were processed, or approximately $54,545 \mathrm{~kg}$. (60 tons). All of the sample sites where fossils of small mammals were found are within a few miles of Fairbanks, Alaska (Fig. 1) and all are accessible by road. Other localities in the Yukon-Tanana upland were sampled, but did not yield small mammal remains. The lack of small mammals at these localities may be due to the smaller size of the samples. All mining cuts that were sampled were either still being mined or had been abandoned so recently that revegetation was incomplete. Eva Creek was the best cut for sampling as it was being mined throughout the study period, and had sediments ranging in age from Illinoian to Recent. Ready Boullion Bench had the same stratigraphic spectrum but had not been worked for several years. The Sheep Creek cut and West Dawson cut on Goldstream Creek had segments of the section exposed, but were mostly covered by vegetation and colluvium. Most of the collections were made during the summer of 1965. Following are descriptions of the localities and the zones that were sampled. Although they are written in the present tense, subsequent mining and/or erosion almost certainly have altered the exposures and resulted in change in the thickness of some units.

\section{Locality: Eva Creek}

This exposure is about $15 \mathrm{~km}$. from Fairbanks near Nenana Road (Fig. 1). The section is illustrated in Fig. 2.

EVA 1. Immediately above the gravels and permeating it to some degree is a dark organic bed averaging less than $3 \mathrm{~m}$. in thickness. Near the contact with the gravels this zone contains numerous iron-stained woody fragments in an advanced state of decay. Although the rest is fairly rich in organic material the plant fragments are very small and carbonized black. Some bedding can be seen within this green layer as a result of differential erosion by the jet of water. There are a few small brown lenses near the top. Two samples (Nos. 1 and 2) were taken from the base and the top of this zone. They consisted of 428 buckets and 193 buckets respectively.

EVA 2-1. Eva 1 grades upward into an olive brown layer designated here as 


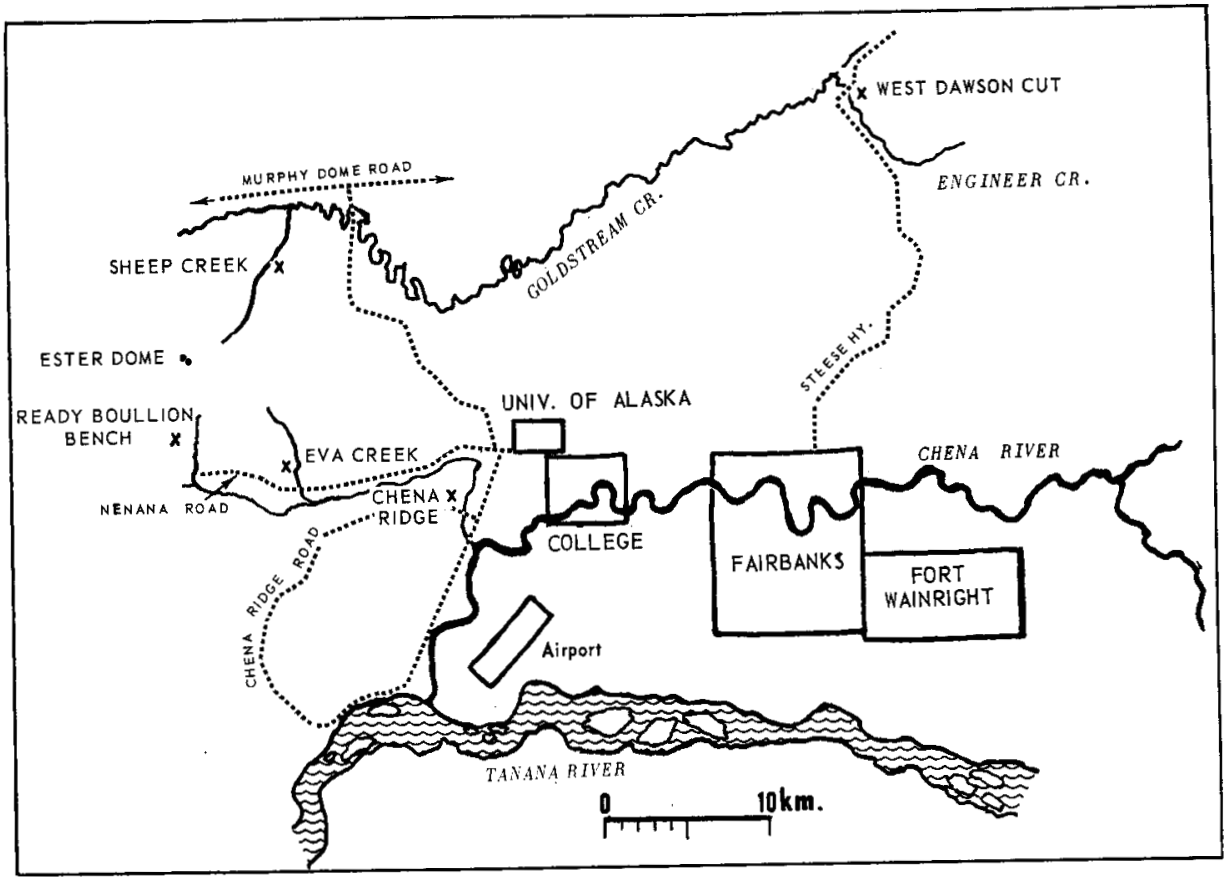

FIG. 1. Map indicating location of the five sampling sites: Eva Creek; Ready Boullion Bench; Sheep Creek; Chena Ridge; West Dawson Cut.

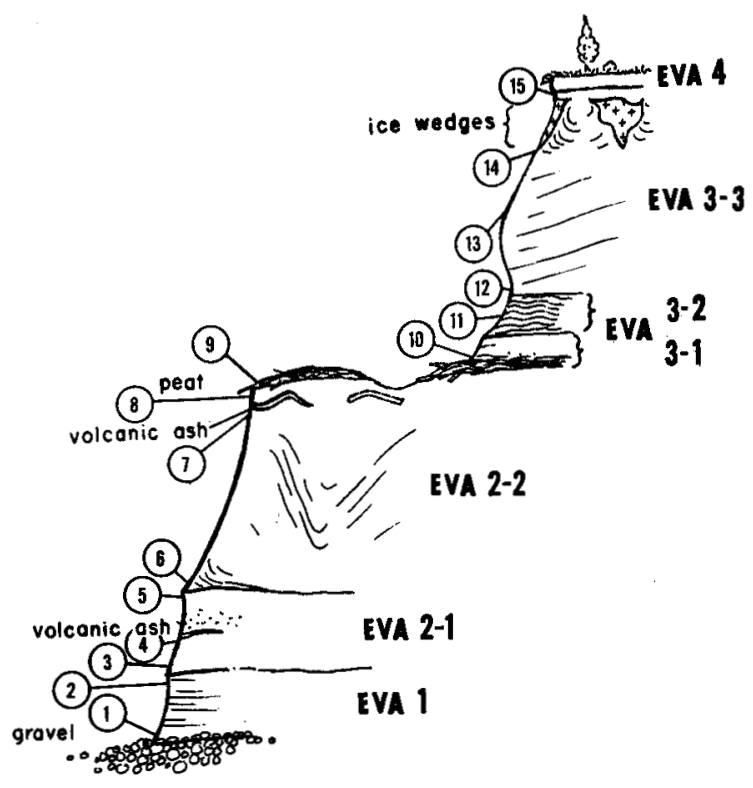

FIG. 2. Eva Creek section. Sample numbers and locations are shown by numbers in circles. See text for description. 
part of the next unit, Eva 2. This unit is slightly thicker than Eva 1. The lower part is well bedded and has fine gravels mixed with the muck. It is organic but lacks large fragments. The upper portion does not have gravel-sized particles, but does contain many small sticks. The wood fragments from this layer are stained dark brown and are crusted with a film of iron oxide. A sample (No. 3) of 52 buckets was taken from the base of Eva 2-1. Another sample (No. 4) of 52 buckets was taken from the middle, and a third sample (No. 5) of 106 buckets was taken from the top. Sample No. 4 includes a thin $(1 \mathrm{~cm}$.) volcanic ash bed.

EVA 2-2. Above Eva 2-1 is another layer of loess and/or reworked loess. It can be characterized by a greenish cast of the freshly exposed silt. The thaw zone tends to become brown after drying. This is the thickest unit in the section, about $12 \mathrm{~m}$. Unlike all other beds in this section Eva 2-2 is almost devoid of organic material. This zone is comparatively featureless except near the base where some bedding can be seen and near the top where a thick contorted and faulted ash is present. This ash bed is up to $35 \mathrm{~cm}$. thick in some places and thins to less than a few milimetres in others. Three samples were taken: from just above the contact with Eva 2-1 (No. 6), immediately below the ash (No. 7), and from the top of subunit No. 8. The samples consisted of 116, 168, and 254 buckets respectively.

EVA 3-1. At Eva Creek, between the characteristic greenish Eva 2-2 and Eva 3-3, which are both widespread in the Fairbanks area, there is a zone which may represent reworking of Sangamon fossils in Wisconsin deposits. At the base of this subunit there is a very resistant layer of compacted plant material in a silt matrix. Although rather thin, about $2 / 3 \mathrm{~m}$., it is the zone most resistant to removal by a jet of water, which accounts for the bench contour at the Eva exposure. It also takes great effort to process by screen washing. There are many tree trunks and roots imbedded in this layer. The diameter of the largest root is over $20 \mathrm{~cm}$. All are aligned roughly parallel to the old valley axis (north-south). The peat grades into brown organic silt of varying thickness near the contact with the Eva 2-2. At places there are lenses of peaty material intercalated with the upper part of Unit 2-2 for a few centimetres, but on the whole the boundary is rather sharp. A sample (No. 9) of 125 buckets was taken from the basal portion of this zone. A carbon date from wood from this zone was 56,900 B.P. (Hv. 1320). Gradationally overlying the compact peaty silt is a heterogeneous zone which is quite organic but not peaty. The colour is variable, and the beds are contorted, with intermingled dark, light brown, and olive green silt. This bed averages slightly over one metre in thickness. Sample (No. 10) from the basal portion of this zone consisted of 116 buckets.

EVA 3-2. The brownish silts of Eva 3-1 grade rapidly upward into a very well-bedded gray-green laminated zone less than $2 \mathrm{~m}$. thick. The beds have wavy contours with frequent lenses of sirloin ice or Taber ice (Péwé 1957). Perhaps because of the ice, this unit disaggregates very easily with screen washing. A sample (No. 11) consisted of 96 buckets and was taken from the central part of the bed.

EVA 3-3. Overlying Eva 3-2 is a thick homogeneous layer of at least partially reworked frozen loess. It is dark gray when wet and gray to buff when dry. No 
large plant fragments are present, but small fragments appeared in the screens. Few bedding planes could be found, which is fairly characteristic of this zone throughout the Fairbanks area. This zone is about $12 \mathrm{~m}$. thick at the Eva cut. An ice wedge reticulum is exposed near the top, which penetrates about half the thickness of this unit. Large mammal bones (Bison sp.) found in place came from the ice wedge zone. Four samples were taken from this unit: from the base, No. 12, 140 buckets; from $6 \mathrm{~m}$. above the base, No. 13, 177 buckets; near the base of the ice wedges at above midpoint of the bed, No. 14, 88 buckets $(24,000$ \pm 650 B.P., I-2116); and from the east side of the cut immediately below Eva 4, No. 15,131 buckets.

EVA 4. The contact of this very organic zone and the Eva 3-3 is very abrupt. Although the silt in Eva 4 is about the same colour, it contains much more plant material than Eva 3-3, including peat layers and large tree roots and stumps. In some places there is more plant material than silt. The subunit was not sampled at this locality.

\section{Locality: Ready Boullion Bench, East Wall}

This exposure is about $17 \mathrm{~km}$. from Fairbanks near the community of Ester Dome (Fig. 1). The section exposed at Ready Boullion Bench is illustrated in Fig. 3.

RBB-1. On the east wall there are two gravel beds. The colour of the silt above the first gravel is rather variable but tends more toward brown than the beds above it. This silt unit averages about $21 / 2 \mathrm{~m}$. in thickness. A sample (No. 16) of 117 buckets was taken from just above the lower gravels.

RBB-2. A greenish layer above the second bed of gravels is almost identical

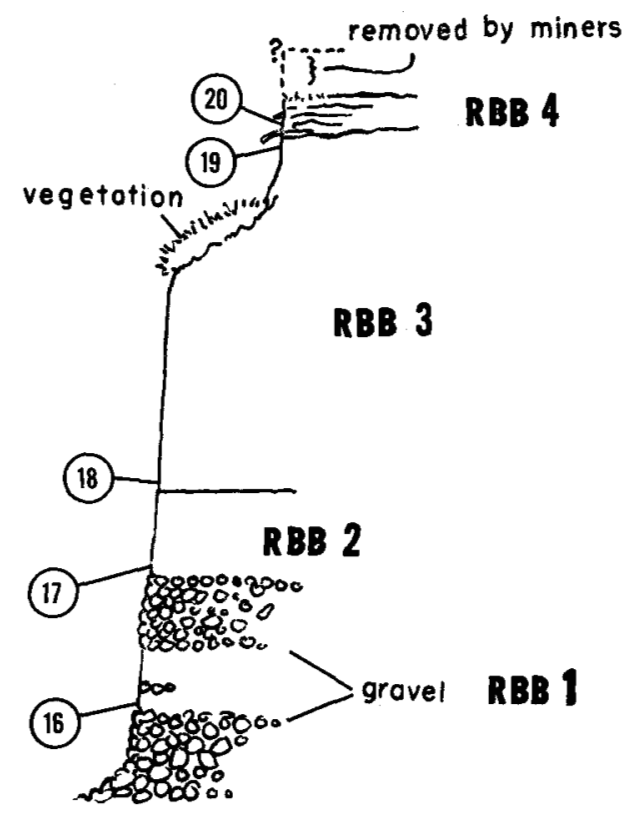

FIG. 3. Ready Boullion Bench section. See text for description. 
in texture and colour to its counterpart at the Eva Creek cut. This zone is, however, not so thick, averaging only $2 \mathrm{~m}$. at this locality. It is mainly inorganic with few macroscopic plant fragments, but there are a few thin layers of black carbon near its base. A sample (No. 17) of 115 buckets was taken at the base, just above the upper gravels.

RBB-3. This zone is also almost identical to its counterpart at Eva Creek, and ranges from 12 to $14 \mathrm{~m}$. in thickness. Since the east wall has not been worked recently the ice wedges apparently have melted back, leaving a bench in the upper half of the unit. Some early successional plants are present on this platform. The contact with the underlying RBB- 2 is rather sharp. There are, however, a few interstratified zones at some places along the contact zone. A sample (No. 18) of 77 buckets was taken from the basal portion, and another (No. 19) of 78 buckets from the top.

RBB-4. The nature of the contact and the amount of organic material imbedded in this zone is similar to Eva 4 at Eva Creek. Large plant fragments are common, quite in contrast to the underlying structureless RBB-3. A sample (No. 20) of 119 buckets was taken just above the base.

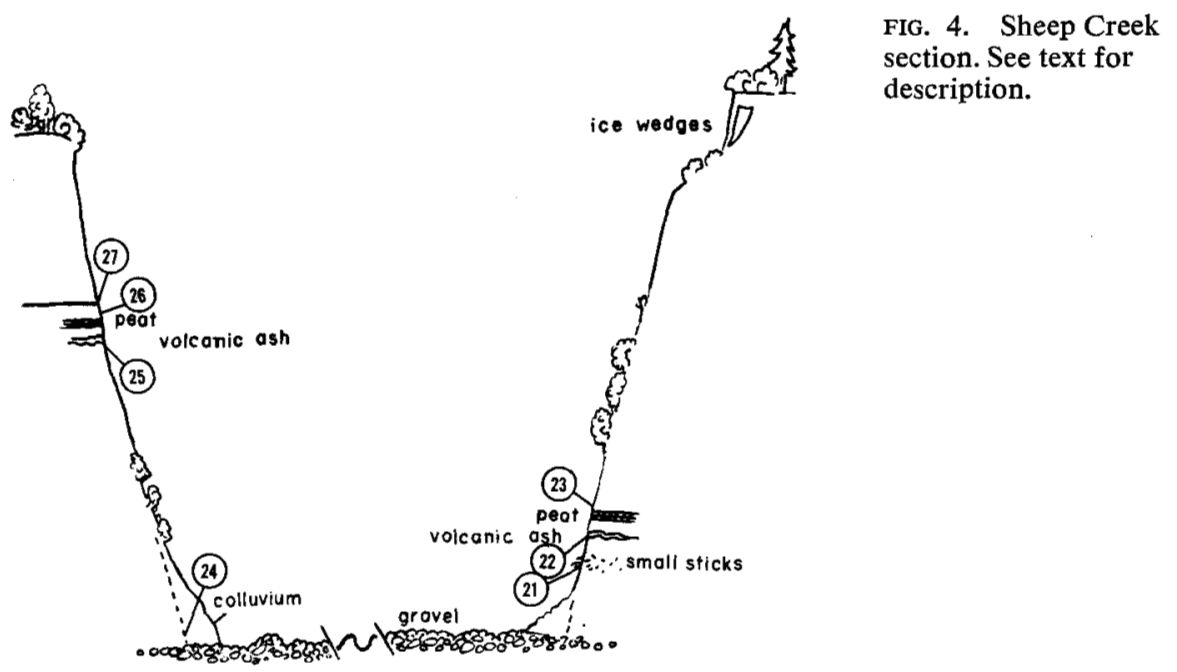

\section{Locality: Sheep Creek}

This cut is on the north side of Ester Dome about $17 \mathrm{~km}$. from Fairbanks, just off the Murphy Dome Road (Fig. 1). An incomplete section is illustrated in Fig. 4.

WEST WALL. The west wall is well vegetated, as the cut has been inactive for some time. However, the base has only a thin plant cover and was re-exposed for sampling. The muck just above the gravels is brown with olive drab bands and contains large fossil roots and stems similar in state of decay to those in the Eva 1 zone at Eva Creek. About $3 \frac{1}{2} \mathrm{~m}$. above the gravel is a thin very woody silt bed containing numerous small sticks. A sample (No. 21) of 90 buckets was removed from this layer. About $1 \frac{1}{2} \mathrm{~m}$. higher was an intermittent ash layer 
from which a sample (No. 22) of 175 buckets of silt and ash was taken. One metre above the ash was an irregular but well-developed peat bed about $20 \mathrm{~cm}$. thick. A third sample (No. 23) of 153 buckets was taken from immediately above this peat.

EAST WALL. The zone sampled on the east wall is much higher than that sampled on the west wall. The lower portion of the exposure is covered with thick colluvium and vegetation. A greenish zone, similar in appearance to that designated Unit 2 at other localities was followed upward to its contact with Unit 3. A layer of peat occurs $1 \mathrm{~m}$. below the contact of Units 3 and 4, approximately $15 \mathrm{~m}$. above the gravel. About $1 \mathrm{~m}$. below the peat is a thick volcanic ash layer. Four samples were taken from this wall. One sample (No. 24) of 116 buckets was taken from an area where the vegetation could be removed at the gravel-silt contact. This silt is quite brownish but contains no large plant fragments. A second sample (No. 25) of 94 buckets was taken from immediately below the thick volcanic ash layer. A third sample (No. 26) consisted of 102 buckets taken immediately above the peat. A final sample (No. 27) of 64 buckets was taken from the uppermost portion of the green zone.

\section{Locality: Chena Ridge}

This locality is $10 \mathrm{~km}$. from Fairbanks on the Chena Ridge Road (Fig. 1). The deposit is an example of unreworked loess (Fairbanks loess; Péwé 1965). One sample (No. 28) was taken from the first bank on the right after crossing the Chena River Bridge. It consisted of 60 buckets taken from below an ash layer.

\section{Locality: West Dawson Cut}

This area is $15 \mathrm{~km}$. north of Fairbanks near the confluence of Engineer Creek and Goldstream Creek (Fig. 1). A sample (No. 29) of 70 buckets was removed from around a partial mammoth skeleton. The locality is on the north bank of Engineer Creek, about $200 \mathrm{~m}$. from the road, and slightly above the gravel. This muck is quite organic and contains many plants and plant fragments. Several small sticks have been dated as more than 39,000 years B.P.

\section{SPECIMENS RECOVERED}

A summary of dental material recovered from the screened samples is presented in Table 1. The most striking pattern that emerges is the great preponderance and chronological spread of Microtus gregalis specimens. This species occurs in every major stratigraphic unit ranging in age from Illinoian to late Wisconsin. This same species has also been identified from deposits of Illinoian age (Riss glaciation) in Siberia (Vangengeim 1961). Three other microtine species are present in the assemblage: Lemmus sibericus, Dicrostonyx torquatus, and Microtus xanthognathus. A schematic compilation of species according to strata is plotted on a generalized stratigraphic map in Fig. 5. Although there are only 4 specimens of Lemmus, none occurs in the middle of zones thought to have been deposited during a full glacial stage, i.e. Units 2 and 3. Five of the 6 specimens of Dicrostonyx occur in beds representing late or late-middle Wisconsin time and 
TABLE 1. Summary of Identifiable Small Mammal Fossils from the Fairbanks Area.

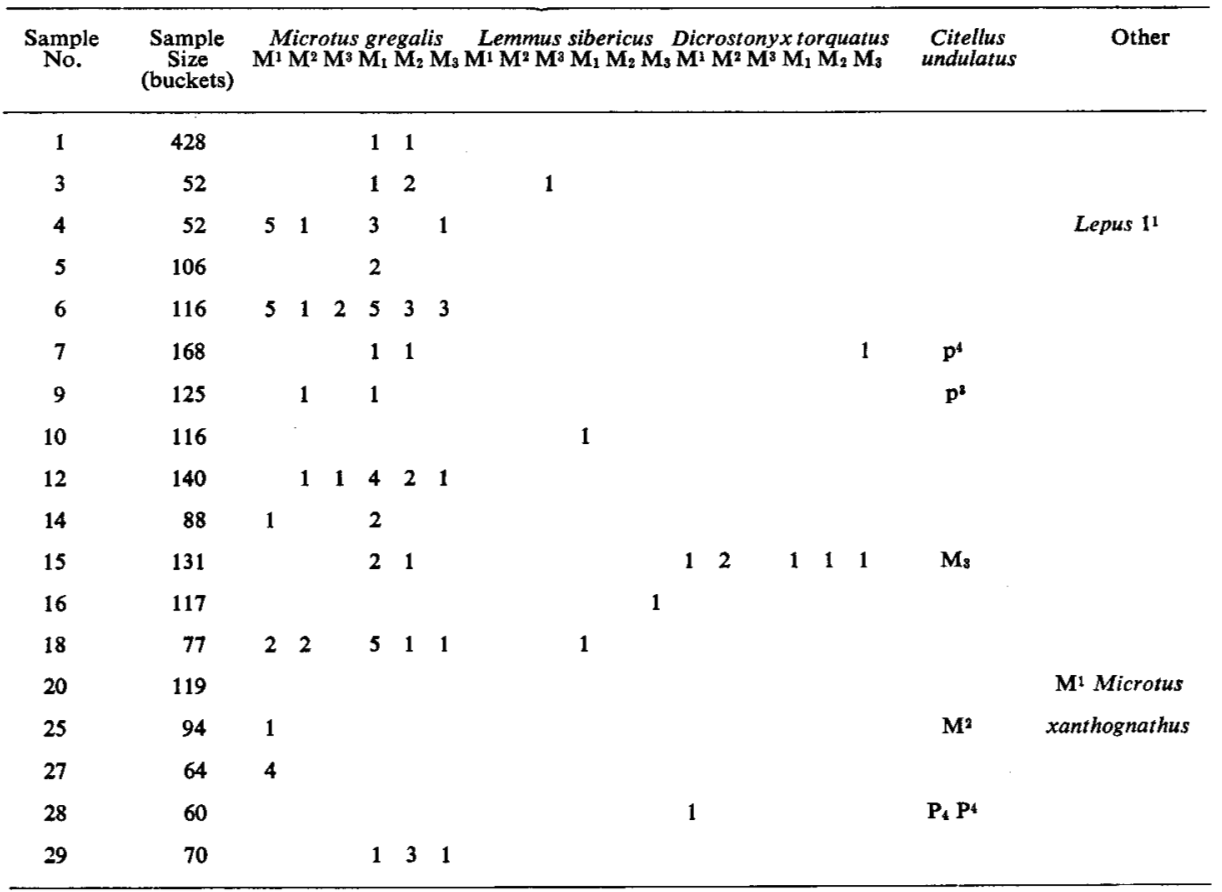

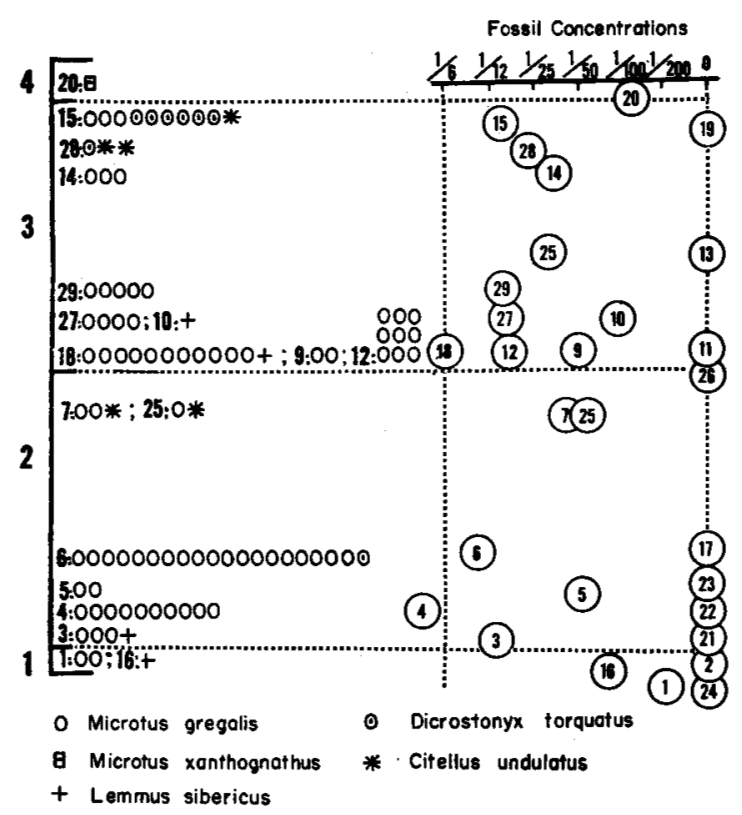

FIG. 5. Composite stratigraphic representation showing the approximate chronology and abundance of the different fossil species. The 4 units are numbered on the left. Sample numbers are also listed on the left with the fossils found in each. The index of fossil concentration is expressed as the number of individual teeth over the total buckets (approx. 12 quart capacity) of silt processed. The numbers in circles also represent the sample numbers. 
the sixth from just above Unit 1 . The very large tooth, tentatively identified as $M$. xanthognathus, came from the basal portion of the post-glacial muck (Eva 4).

The most frequent tooth recovered of $M$. gregalis was the $\mathrm{M}_{1}$. These specimens have eight closed, or almost closed, enamel fields (the posterior loop, 6 alternating triangles and the anterior trefoil). The closure of the sixth triangle tends to be incomplete, although in several specimens it is completely closed. The $\mathbf{M}^{1}$ and $\mathrm{M}^{2}$ both lack accessory angles as in $M$. pennsylvanicus and $M$. agrestis. The $\mathrm{M}^{3}$ is quite simple in form with only three re-entrant angles on each side. Taken together with the small size of the teeth, these tooth characteristics narrow the identification down to $M$. gregalis. Although there is considerable crown variation within the living representatives of this species, no population to my knowledge has a more complex $M_{1}$ than these fossil specimens. The Palearctic subspecies are particularly prone to having less complex teeth (Ognev 1950). Table 1 indicates that the number of $M$. gregalis teeth declines in frequency in this sequence - $M_{1}, M^{1},\left(M_{2} M^{2} M_{3} M^{3}\right)$. This decline also follows a general decrease in tooth size. This pattern seems to be a general phenomenon and has occurred in other microtine collections that I have studied (Guthrie 1965). The correlation may be a product either of preservation or of recovery. This general relationship of size to differential preservation or recovery is also present in elements of much larger species (Guthrie 1966).

The ground squirrel Citellus undulatus was found to range from immediately below the volcanic ash layer in the Eva 2-2 unit to the late Wisconsin. These teeth are indistinguishable from those of the modern arctic ground squirrel. Fossil nests and seed caches of this species are common in interior Alaska. A study of the seeds from these caches is now in progress. This sample, taken from just below the Eva 2-2 ash is the earliest reported record of this species from the Fairbanks area. The latest occurrence was from the Wisconsin D sample (No. 15) taken at Eva Creek from the uppermost Wisconsin. A fossil squirrel burrow also was uncovered during excavation of the late Paleoindian "campus site" on the University of Alaska campus by Mr. Morris Morgan of the Department of Anthropology and Geography. Artifacts overlying by only a few centimetres the bed containing the entrance hole indicate an extremely late Wisconsin or early post-glacial date for the squirrel burrow.

There is considerable difference in the size and shape of the two Lemmus $\mathrm{M}_{1}$ 's. The smaller of the two (UA71) does not appear to be a young tooth; its parallel sides indicate that the mature crown pattern had been attained. The size of the large tooth (UA86) falls within the range of the modern species of Lemmus, but the smaller tooth is on the extreme tail of the present variation. Had the smaller tooth (UA71) been found in Eurasia it undoubtedly would have been described as Myopus, the wood lemming, inasmuch as the $\mathrm{M}_{1}$ 's of Myopus and Lemmus differ only in size. The fact that lends added suspicion that this small tooth may represent Myopus is its occurrence at almost the same horizon as UA86, although at different localities. This raises the unlikely possibility of 2 contemporaneous populations of Lemmus which differ considerably in tooth size. However, since this is the first time that the possibility of Myopus occurring in the Nearctic has arisen, it may be best tentatively to assign both teeth to Lemmus at this time. 


\section{ECOLOGY OF EXISTING SMALL MAMMAL COMMUNITIES IN THE NORTH}

Since there probably are no extinct species represented, it should be possible to derive some direct information pertaining to the paleoecology of the Fairbanks area. An obvious approach would be a comparison of this assemblage with existing communities of the same species. Unfortunately, most of our knowledge of small mammal ecology concerns more southern species. The greater part of the work in the north has been related to density cycles. There is, however, enough information about northern small mammals to allow some general statements about the intracommunity relationship and habitat preferences.

One does not find complete agreement of ecological interpretations by investigators who have worked on either the Siberian or Alaskan small mammals. Part of the difficulty may be differences in interpretation, but a significant portion seems to be related to the actual differences between study areas or population densities. The degree of species' dominance and the range of habitat preference appear to be related to population levels (Pitelka 1957; Krebbs 1964; Pruitt 1966). Because of the cyclic density fluctuations strict ecological boundaries are difficult to establish. A population which is studied in its high may occupy a spectrum of habitats that is different from that of the same population at the low of its cycle. Since a species at its peak density almost invariably will encroach upon the typical habitats of other species, a study of the species at its low would probably give more information on the priority of habitat preferences. Many northern microtines can adjust their diets to a number of different plant species. With but few exceptions, any attempt to relate one microtine species to one or two plant species has had little success. The physical features of the landscape are perhaps a more important element governing habitat preference, and food of secondary importance. Interspecific interaction and density are still, of course, major influencing variables. Drainage (which determines whether conditions will be wet or dry), type of snow cover, and degree of overhead protection seem to be among the most critical factors. Pruitt (1966) emphasized the effect of snow cover on microhabitat preferences, and many other investigators have referred to the effects of drainage and protective overhead vegetation.

The following is a brief discussion of several individual species of small mammals found in northern Alaska today which relate to the paleoecological interpretations given here.

Microtus gregalis ( $=M$. miurus), the singing or gregarious vole.

Because of its importance in the fossil assemblages analyzed in this study I have given this species a more extensive review than others. Rausch (1964) synonomized all Holarctic species of the subgenus Stenocranius with the gregarious vole, $M$. gregalis. The species is widespread in Eurasia, but has a very limited distribution in North America. Disjunct populations are scattered over Alaska and some of the extreme northwestern parts of Canada. A vole smaller than $M$. oeconomus, it appears to have a dietary range almost as broad. Unlike $M$. oeconomus, the singing vole is seldom found in very wet habitats, but rather prefers dry soils. Both Rausch (1951) and Bee and Hall (1956) found the singing vole to be the most abundant microtine in the Brooks Range. When found in the 
lowlands it is usually confined to well-drained microhabitats, either steep slopes with early successional plants or dry bottomlands near cutbanks (Bee and Hall 1956; Pitelka 1957; Kopein 1958, and others). Mayo (1963) characterized $M$. gregalis habitat at Cape Thompson in western Alaska as grass-sedge-Cassiope, with grasses more common than sedges. Kopein (1958), who worked on the Siberian subspecies, found the diet to be composed of cottongrass, sedges, wormwood (Artemesia tilesii), willows, and horsetail (Equisetum).

Pruitt (1966) found $M$. gregalis to be associated with areas of deep snow drifts in winter, but concluded that other factors also determine its occurrence. In Ognev's (1950) review of the Russian $M$. gregalis he found that it fed primarily on herbs, and preferred dry soils. Several of his comments on the ecology of this species relate to its biogeography. Unlike the new-world form, which has a very northern distribution, the Asiatic form extends southward beyond $40^{\circ}$ latitude. In the south it is primarily a denizen of the steppes. It is found in greatest abundance in the virgin steppes and also in old steppe fallow, some wooded steppes, and plowlands. From this Ognev concluded that $M$. gregalis is a southern form which has invaded a specialized habitat in the north, where it selects food that is the same as or is similar to the kind it was accustomed to farther south: wormwood, grasses, lillywort, coltsfoot and other herbs. The frequent association of $M$. gregalis with sage or wormwood (Artemisia) is not surprising since this plant also has a well-known preference for dry well-drained soils.

With but a few exceptions the present distribution of $M$. gregalis in Alaska follows the high alpine terrain. The overall distributions of this species in Alaska and that of the dall sheep, Ovis nivicola $(=O$. dalli) have striking similarities, particularly when one considers that in some areas where $M$. gregalis is found sheep are now absent but were present in the recent past. In most areas where $M$. gregalis has not been found and sheep do exist, there has been almost no small mammal trapping.

\section{Clethrionomys rutilus, the red back vole.}

This is a Holarctic species which ranges through the northern half of Eurasia, almost all of Alaska, and the northwestern third of Canada. There are two other Nearctic species in the genus. These are virtually allopatric (Hall and Kelson 1959). In the Palearctic there are a number of species, several of which are sympatric over much of their range. Ecologically this species appears to be the Peromyscus of the north. Its diet is quite varied but tends more toward fruit and seeds than other microtines (Corbet 1966). It is fairly ubiquitous in a large range of habitats. The consensus is that its local distribution is tied closely to the presence of overhead cover. In the woodlands to the south this generally means that it is more common in forests than in oldfield clearings. However, it does manage to exist in tundra by using large-boulder fields (Bee and Hall 1956) or dwarf birch (Betula) and dwarf willow (Salix) for the necessary protection. In some tundra areas Clethrionomys is quite common in cotton grass (Eriophorum) tussock meadows. Mayo (1963) has suggested that these tall tussocks may serve as overhead protection. In the western Arctic, Pruitt (1966) found that red back voles occurred with microtus oeconomus more frequently than by chance alone. 
Lemmus sibericus ( $=L$. trimucronatus), the brown lemming.

Rausch (1953) considered the Nearctic brown lemming to be conspecific with the Siberian $\mathrm{Ob}$ lemming. There is another species, Lemmus lemmus in the Old World which is restricted to the most northern part of the Scandinavian Peninsula. Some authors (e.g. Sidorowicz 1960) have even suggested that there is only one species in the genus. Lemmus sibericus is found throughout the extreme northern portion of Eurasia (Ognev 1950). In the Nearctic it is found in the northern half of Alaska and northwestern part of Canada (Hall and Kelson 1959). The general conclusion of most studies of the brown lemming is that it prefers wet meadows. Also, it is almost completely dependent on a diet of sedges and grasses. Kopein (1958), working with the Siberian brown lemming found that its diet was composed of sedges (Carex and Eriophorum) almost to the exclusion of other plants. In the summer the top parts and in the winter the roots and lower parts of the stalk are eaten. Rather than eating the more digestible plants, the brown lemming eats great volumes of sedge which is broken down in its exceptionally long digestive tract (ten times longer than its body; Kopein 1958). In some areas Lemmus lives on grasses, in other areas it eats mainly sedges, and in still other areas both sedges and grasses (Ognev 1948). A number of other plants are eaten but most of these are only minor dietary components. Bee and Hall (1956) and Pitelka (1957) found Lemmus to be most abundant on the northern part of the Coastal Plain of Alaska. It is found there on the low ridges among wet meadows produced by the polygonal ground relief. Thompson (1955) found in the lemming population at Point Barrow, Alaska, a rather inflexible microhabitat preference during the summer. Few animals venture far from the moist polygonal troughs. He also found that the staple food of Lemmus is the vegetative parts of grasses and sedges. As in North America, the Siberian lemmings are not restricted to tundra, but seldom occur far from moist habitats (Ognev 1948) except in times of high population densities.

Dicrostonyx torquatus $(=D$. groenlandicus), the varying or collared lemming.

Dicrostonyx is a circumpolar genus occupying the northernmost part of both North America and Eurasia. Rausch (1953) has included all members in the genus under one species, as there appear to be no sharp differences between the Palearctic and Nearctic forms, and the characters used to separate the North American species show intergradation. As the common name implies, this species develops a white pelage in the winter. Another unusual characteristic of this genus is a great enlargement of the claws on the forefeet in winter, apparently to enable it to claw through compacted snow. These features and the extreme northern distribution of the collared lemming illustrate its specialization for existence in northern climates.

There probably is more disagreement about the ecology of this species than of any other northern microtine. Bee and Hall (1956) described the habitat of the collared lemming as the undulating uplands on the Plateau Province or the relatively sloping ridges on the Coastal Plain. In their study areas the collared lemming was almost invariably associated with cotton grass, Eriophorum. They 
found that it was more restricted to one plant community than any other microtine, and had fewer small mammal associates. It ate grasses and sedges like the brown lemming but more tubers, shrub leaves, and bark than Lemmus. They concluded that Dicrostonyx was generally found in drier areas than the brown lemming. Pitelka (1957) and Krebs (1964) also found that Dicrostonyx prefers drier habitats than Lemmus. Ognev (1948) agreed with several of these interpretations in his review of the Palearctic Dicrostonyx. He regards the collared lemming as an inhabitant of rocky tundra and dry upland areas, but states that it does occur in the damp tundra in some areas. He also finds that it is less stenophagus than Lemmus. Pruitt (1966) and Mayo (1963) working with Dicrostony $x$ in northwestern Alaska did not find the strict association that Bee and Hall (1956) did with Eriophorum. Instead, they found that it was associated with frost scars, frost heaving or broken ground. It was a creature of the rocky uplands or areas where the soil and vegetative mat are broken by frost action. They emphasized that Dicrostonyx prefers ecotone communities. Pruitt (1966) showed, by coefficient of association analysis, that Dicrostonyx was associated with Lemmus much more than could be explained by chance, and with $M$. oeconomus much less than by chance. It seems that Dicrostonyx is seldom found isolated from other microtines and seldom is it the dominant member of any local microtine community.

Microtus oeconomus, the tundra vole.

Like all other microtines described in this section, the tundra vole has a Holarctic distribution. In North America it is almost confined to Alaska but occurs throughout most of northern and central Eurasia. The tundra vole without question is one of the most common Alaskan microtines. It is found in almost every habitat, but is more common in the unforested, damp lowlands. In Pruitt's (1966) and Mayo's (1963) studies at Cape Thompson, Alaska, the tundra vole was found to be the only ubiquitous species, occurring with every vegetation type, except where $M$. gregalis was found. However, in the Brooks Range Rausch (1951) found it restricted to fewer habitats than $M$. gregalis. Bee and Hall (1956) found that $M$. oeconomus is most commonly found in wet meadows, around lakes, streams or marshes. It occurred with Lemmus more frequently than any other species. On the Arctic Coastal Plain Lemmus is most abundant in the north and $M$. oeconomus most abundant in the southern portion near the Plateau Province. Quay (1951) and Pitelka (1957) also state that $M$. oeconomus prefers very wet areas. In the areas studied by Pitelka (1957), $M$. oeconomus appears to be restricted to low wetland communities, characterized by Carex aquatilis and subdominant grasses. Pruitt (1966) found that the tundra vole was associated most commonly with Lemmus and secondly with Clethrionomys. From my own observations in the Yukon-Tanana upland, I can conclude that it is the dominant species of Microtus of that area, and inhabits the unforested areas, while Clethrionomys is more common in the forests. The tundra vole appears to have an extremely wide tolerance to different habitats, but may be locally restricted by competition with other microtines. 


\section{PALEOECOLOGICAL INTERPRETATION}

One could assume from the Fairbanks assemblages that $M$. gregalis was the dominant microtine during the time the muck was deposited. There is no obvious preservation bias that would have selected for this species over others in a mixed community. In actuality, $L$. sibericus and $M$. oeconomus probably would be the species most likely to be preserved because they prefer the wet lowland habitat where the greatest deposition takes place. Since $M$. gregalis is one of the smaller microtines, one might even expect that the teeth and bones would be both more likely to be destroyed or overlooked more often by the collector than those of larger species.

If these samples are representative of the late Pleistocene assemblage throughout the Yukon-Tanana upland one can conclude from the abundance of $M$. gregalis.that the upland was a well-drained unforested area, rather unlike the unforested areas there today which tend to be dominated by wet tundra and bogs. It suggests that the well-drained alpine meadow expanded down almost to the river flats in interior Alaska during the last two glaciations. The occurrence of sheep fossils at adjacent localities (Guthrie 1968) corroborates this idea. Others (Repenning et al. 1964) have shown that the tree line lowered at least $300 \mathrm{~m}$. during the Wisconsin glaciation. In an earlier study of the large mammal community from the same area (Guthrie 1968), I concluded that over 95 per cent of the large mammal biomass belonged to grazers, mainly bison, horse, and mammoth. Several other species of large mammals that were present are also closely associated with grasslands: saiga antelope, wapiti, sheep, and camel. The dominance of $M$. gregalis in the fossil community is consistent with the conclusions drawn from the large mammal community. $M$. gregalis seems to be the microtine most likely to become dominant in a vegetational community that could support that particular pattern of large mammal species.

Lemmus occurs near the zones where larger plant fragments are found, i.e. near the interglacials (or interstadials?). Although the frequent occurrence of the arctic ground squirrel fossils does not necessitate an interpretation of the local vegetation pattern as meadowland, the alpine meadow areas are their most preferred habitat. Away from this habitat they occur in disturbed areas with subclimax vegetation (Carl, unpublished manuscript).

The absence of any species from a fossil fauna is negative evidence and does not at all mean that the animal was not there. It does, however, suggest that the relative densities of these missing species may not have been very great. Clethrionomys rutilus and $M$. oeconomus occur throughout most of interior Alaska today and are the dominant microtines. The lack of these species in the fossil fauna is a strong argument for the absence of their preferred habitat. Again, this picture is consistent with the comparison of the fossil and recent large mammals. The moose, Alces, which lives in wet woodland parks or moist tundra, comprises the greatest biomass in the modern community. In the fossil community it was quite rare (Guthrie 1968). There are at least superficial similarities between the habitats preferred by moose and $M$. oeconomus.

One can only draw general conclusions about the climate from the fossil small 
mammals. Since a lowering of the tree line must have taken place, this suggests cooler or shorter summers, but says nothing about winter temperatures. The increased distribution and dominance of $M$. gregalis does suggest a deep summer thaw, as this species prefers dry, well-drained soil, and the associated vegetation; also perhaps heavy drifted snow cover.

Colinvaux's (1964) pollen profiles from the Seward peninsula suggests dry or at least meadow tundra habitat during the glacial maxima. Colinvaux showed that the shrubs are supplanted by herbs running in a continuum from zones II, I, and 0 . He interpreted the vegetation in zone 0 as a "more meadow-like grassland," and says "a grassy prairie flourished in a climate too cold for dwarf birch to survive." Several pollen profiles from the Beringian Refugium area showed a medium to high percentage of sage or wormwood, Artemisia, pollen (Livingstone 1955; Heusser 1966; Colinvaux 1964). Colinvaux used this to argue that the dry sites which Artemisia characteristically prefers must have been more abundant, at least on the Seward Peninsula, during the Wisconsin glaciation. Petrov (1963) also found an abundance of Artemisia pollen in the Pleistocene deposits of Eastern Siberia. The community analysis of the late Pleistocene fossil large mammals from the Beringian Refugium also supported the idea of a dry tundra (Guthrie 1968).

\section{DISTRIBUTION CHANGES}

The fossil small mammal faunas from the Fairbanks localities differ considerably from the modern fauna in that same area. The fossil large mammals also differed from the present community (Guthrie 1968), but in the case of the large mammals it was part of a pattern of extinction that affected most of the Holarctic. There are a number of distributional changes that this small mammal fauna documents, but none involve widespread extinctions. Three of the fossil species are now absent from the Yukon-Tanana upland: Microtus gregalis, Dicrostonyx torquatus and Citellus undulatus. Several species of microtines which are now found in the Yukon-Tanana upland are not present as fossils; Microtus pennsylvanicus, Microtus longicaudus, Microtus oeconomus, Synaptomys borealis, Ondatra zibethicus and Clethrionomys rutilus. One recent species, Microtus xanthognathus, was only found in Holocene deposits. Because of the small sample sizes it cannot be stated that these species did not occur in the glacial refugium during the last glaciation. However, the distribution patterns of two of the species, $M$. pennsylvanicus and $M$. longicaudus, do suggest that they are post-glacial immigrants. Their distributional centres and subspeciation diversity are far to the south, and each has a relatively limited present distribution in Alaska. The distribution patterns of Microtus oeconomus, Clethrionomys rutilus and Microtus xanthognathus look more like post-glacial expansions from Alaska rather than to it. The first two have conspecific counterparts in Asia which strengthens this assumption (Rausch 1963). The present distribution patterns of Ondatra zibethicus and Synaptomys borealis do not present a clear picture as to their possible Pleistocene zoogeography. The separation of Synaptomys into northern and southern species suggests that Synaptomys borealis speciated in a 
northern refugium. However, since neither Ondatra nor Synaptomys have native Eurasian counterparts it would be easy to argue that both are post-glacial immigrants. This same line of reasoning could also be used to exclude Microtus xanthognathus from being a "glacial resident" in Alaska. When Ondatra was introduced into wilderness areas in Siberia, by man, it spread rapidly. It is diffcult to understand why it would not have done so if access had been available in the past. Future fossil collecting may resolve these problems.

In North America Dicrostonyx torquatus is limited to the northern one-third of Canada, north western Greenland, and the extreme northern and western parts of Alaska including the Aleutian Chain. Others (Repenning et al. 1964; Péwé 1957) have reported fossil collared lemmings from the interior of Alaska before. In addition to the Fairbanks specimens a complete skull has been collected by Mr. Harold Schmidt from the Sixty Mile River at the mouth of Miller Creek $10 \mathrm{~m}$. below the surface in Pleistocene muck. The skull is now in his personal collection. Thus it appears that this species occurred over much of the Amphiberengian Refugium during the Wisconsin and possible Illinoian glaciations. Guilday and Doutt (1961) have reported Dicrostonyx in late Pleistocene deposits from Pennsylvania. Apparently the Wisconsin ice sheet separated the Dicrostonyx populations into several disjunct segments. This species was also more widespread during the late Pleistocene in Eurasia. Fossil specimens have been found in England (Hinton 1926) and central Europe (Kowalski 1958). M. gregalis, which inhabited the Yukon-Tanana upland during the late Pleistocene, was also once more widely distributed in Eurasia (Kowalski 1958).

The ground squirrel Citellus undulatus which was present thoughout the Yukon-Tanana upland now occurs in the Alaska Range to the south and in the Yukon Flats to the north. The Yukon basin subspecies Citellus undulatus osgoodi is a rather unusual subspecies that occupies old burns, river banks, or recentlydisturbed areas below tree line. Fossil arctic ground squirrel bones and nests are common in the muck around the Fairbanks area, as well as in other parts of the Yukon-Tanana upland. So, like the two species mentioned above, the ground squirrel appears to have been common throughout the Yukon-Tanana upland in the late Pleistocene, but does not occur there today.

Both Zapus hudsonius, the meadow jumping mouse, and Ochotona collaris, the pika, occur in the Yukon-Tanana upland today, but have not as yet been reported from there as fossils. Perhaps both species existed in the Beringian Refugium, but were so infrequent that they are unlikely to be found as fossils. Both could also be post-Pleistocene colonizers from the south. The modern distribution and subspeciation patterns suggest that Ochotona collaris may have been restricted to the Beringian Refugium during the Wisconsin while the distribution of Zapus hudsonius suggests that it is a recent invader from the south.

\section{EXTINCTION}

The term "extinction" as used in the context of this study applies only to the extinction of the small mammals from the Yukon-Tanana upland. Since it is such a large well-delineated area, within the bounds of the present range of most 
of these species, their disappearance can be considered to be more than just the usual type of range reduction.

The timing of the extinction is between samples No. 19 and No. 20. The former sample was taken at the uppermost Wisconsin boundary and the latter at the earliest post-glacial junction. Radiocarbon dates taken from logs and peat at this boundary from several localities in the Yukon-Tanana upland are between 8,530 years (Péwé 1965) and 7,280 140 (I2240). Although the direct evidence is not as imposing, the fossil large mammal extinctions appears to have occurred at about the same time. The fossil large mammal community was dominated by bison, horse, and mammoth. Interestingly enough, the giant bison $B$. priscus ( $=B$. crassicornis) became extinct before the modern bison did in Alaska. A few finds of $B$. bison in post-glacial deposits (Péwé, personal communication) indicate that $B$. priscus succumbed before $B$. bison. Actually, $B$. bison probably invaded the niche vacated by $B$. priscus for a limited amount of time. The extinction of the small mammals in the Yukon-Tanana upland may, therefore, have resulted from the same changes which caused the extinction of the large mammals in this area.

Tundra areas in the Yukon-Tanana upland, where one might expect to find Dicrostonyx, Citellus, and $M$. gregalis, are somewhat different from the tundra in the Alaska Range and Brooks Range. The grassy alpine meadows that are common in the Alaska and Brooks Ranges are rather limited in the YukonTanana upland. Going back to the original index which referred to sheep as the living large mammal species that was most selective for this grassy alpine tundra, we find only a few quite restricted sheep populations in the Yukon-Tanana uplands on very widely scattered mountains. These sheep populations receive virtually no hunting pressure by man because of their inaccessibility, and they can be considered as making maximum use of their range. As I mentioned earlier the presence of sheep fossils at much lower altitudes and at a considerable distance from these populations suggests that sheep in the area today are relic segments of what once was the dominant pattern in the Beringian region. These sheep ranges have not been sampled thoroughly for modern small mammals because of their inaccessibility. The few that have been sampled did not yield either Dicrostonyx, $M$. gregalis, or Citellus.

Judging from the abrupt transition from the late Wisconsin to recent deposits in the Yukon-Tanana upland a rather abrupt series of changes took place at the end of the Wisconsin glaciation. Silt deposition slowed down drastically. Buried peat beds that contain much moss are very common in the post-glacial deposits, whereas they are quite rare in earlier units. Logs and roots of trees are also found imbedded in growth position in the post-glacial muck. After the close of the Wisconsin the plant community appears to have rapidly become wetter and tended towards a woodland. Péwé (1965) has found abundant evidence that summer thaw line was deeper than its present level in post-Wisconsin times. If during the early Holocene warming these changes resulted in a habitat with even more restricted grassy alpine tundra vegetation than at present, it may account for the elimination of the three species of small mammals (see Fig. 6).

Although it is not too difficult to understand how the arctic ground squirrel 

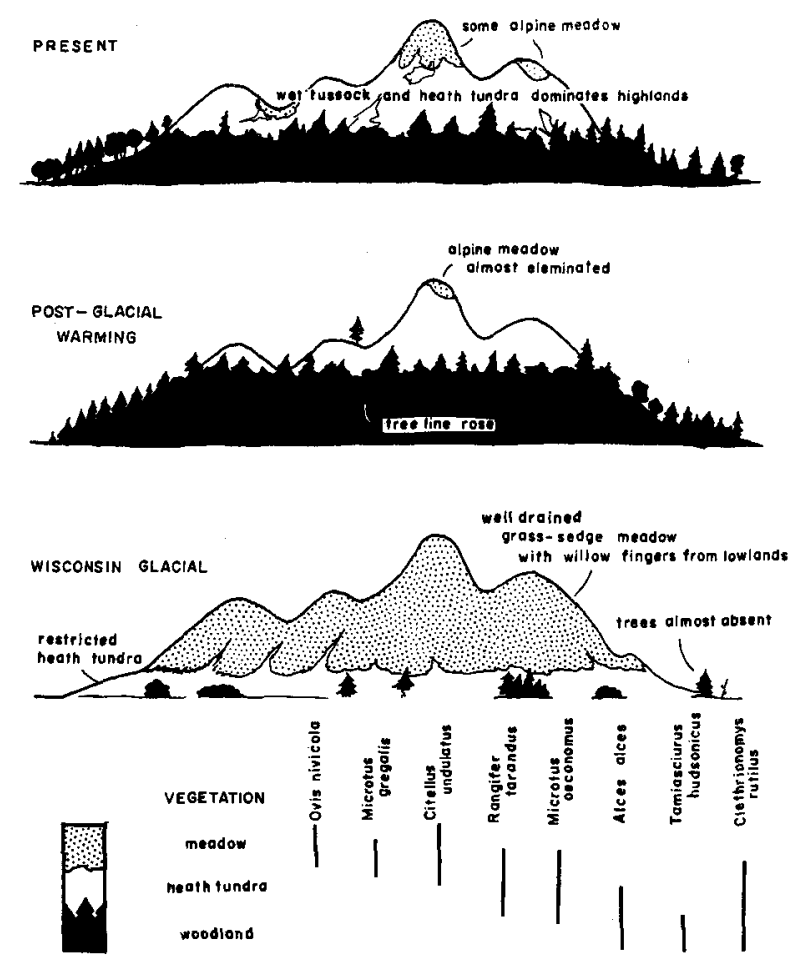

FIG. 6. Diagrammatic illustration of the possible vegetational changes which resulted in the extinction of three small mammal species from the Yukon-Tanana upland. The vegetation is divided into three major zones: the high meadows or grassy herbaceous tundra, the heath or shrub tundra, and woodland. The range of major occurrence throughout these zones of the dominant mammals in central Alaska is shown at the bottom of the diagram.

could have become more restricted, it is difficult to explain how this species could have been completely eliminated from such a large area which at present has such a diversity of habitats. There are many areas in the Yukon-Tanana uplands now that appear to be suitable for ground squirrels. However, rapid population declines are known to occur in this species. Between the summers of 1964 and 1965 , for example, the numbers of ground squirrels on the Yukon flats dropped to a small fraction of their original population. A series of crashes such as this occurring during a period of rapid habitat reduction may have been responsible for their extinction from the Yukon-Tanana upland.

Another explanation is that these 3 species became adapted to a homogeneous vegetation pattern in the Yukon-Tanana upland that was reduced so quickly by the changes following the Wisconsin glaciation that they could not adapt fast enough to the new conditions. Some local races of each of these species are known to adapt to special vegetation patterns and could easily have done so in the fairly isolated habitat of the Yukon-Tanana upland. With the expansion of the present wet tundra and spruce forests, the species Clethrionymus rutilus and Microtus oeconomus, which were probably infrequent subdominants of the refugium community, would have attained their present dominance, competing with Discrostonyx and $M$. gregalis to the point of excluding those 2 species. The elimination or reduction of suitable habitat, and changes in the competition balance, have been used to explain the extinction of some of the large mammals from the same area (Guthrie 1968). 


\section{ACKNOWLEDGEMENTS}

I am particularly indebted to John Matthews, now at the University of Alberta, Edmonton, who was a graduate assistant on the project throughout its duration. He also provided valuable suggestions relating to stratigraphic interpretations. Dr. David Klein and Charles Rowett, both from the University of Alaska, gave advice on the preparation of the manuscript. Financial support for the field work and part of my annual salary was provided by the National Science Foundation (Project GB-3355).

\section{REFERENCES}

BEE, J. W. and E. R. HALL. 1956. Mammals of northern Alaska on the arctic slope. University of Kansas Museum of Natural History Miscellaneous Publication, 8. 309 pp.

ColinvauX, P. A. 1964. The environment of the Bering land bridge. Ecological Monographs, 34: 297-329.

CORBET, G. B. 1966. The terrestrial mammals of Western Europe. London: Whitefriars Press. 264 pp.

GUILDAY, J. E. and J. K. DOUTT. 1961. The collared lemming (Dicrostonyx) from the Pennsylvania Pleistocene. Proceedings of the Biological Society of Washington, 74: 249-50.

GUTHRIE, R. D. 1965. Variability in characters undergoing rapid evolution, an analysis of Microtus molars. Evolution, 19: 214-33.

1966. Differential preservation and recovery of Pleistocene large mammal remains in Alaska. Journal of Paleontology, 41: 243-46.

1968. Paleoecology of the large mammal community in interior Alaska during the late Pleistocene. American Midland Naturalist, 79: 346-63.

HALl, E. R. and K. R. Kelson. 1959. The mammals of North America. New York: Ronald Press. 2 vols. 1083 pp.

HEUSSER, C. J. 1966. Palynology of the Ogotoruk Creek area in Environment of the Cape Thompson region, Alaska. N. J. Wilimovsky, editor; J. N. Wolfe, associate editor. Oak Ridge: United States Atomic Energy Commission. pp. 355-62.

HIBBARD, C. W., E. E. RAY, E. D. SAVAGE, D. W. TAYLOR and J. E. GUILDAY. 1965. Quaternary mammals of North America in The Quaternary geology of the United States. H. E. Wright, Jr. and D. G. Frey, editors. New Jersey: Princeton University Press. pp. 509-25.

HINTON, M. A. 1926. Monograph of the voles and lemmings (Microtinae) living and extinct. Vol. I. London: British Museum of Natural History. 488 pp.

HOPkINS, D. M. (ed.) 1967. The Bering Land Bridge. Stanford: Stanford University Press. 495 pp.

KOPEIN, K. I. 1958. Material concerning the Siberian lemming and the large narrow-skull vole. Bulletin Ural Section Moscow Society of Naturalists, 1: 109-33.

Kowalski, K. 1958. Pleistocene Microtinae from Dziadowa Skala cave in Poland. Acta Zoologica Cracoviensia, 2: 805-23.

Quaternary. Folia Quaternaria Nr. 22.16 pp.

KREBS, C. J. 1964. The lemming cycle at Baker Lake, Northwest Territories during 1959-62. Arctic Institute of North America Technical Paper No. 15.104 pp.

KURTEN, B. 1960. Chronology and faunal evolution of the earlier European glaciations. Commentations Biologicae Helsingfors, 21: 1-62.

LIVINGSTone, D. A. 1955. Pollen profiles from arctic Alaska. Ecology, 36: 587-600. 
Matthews, J. v. 1968. An analysis of three late Pleistocene Coleopterous faunas from the Fairbanks, Alaska region, M. S. thesis, University of Alaska.

MAYo, G. o. 1963. Small mammal habitat preferences at Ogotoruk Creek valley, northwestern Alaska, M. S. thesis, University of Alaska.

OGNEV, S. I. 1948. Mammals of USSR and adjacent countries. 6: 1-508. (Israel Program for Scientific Translations Limited, Jerusalem, 1963).

1950. Mammals of USSR and adjacent countries. 7: 1-626. (Israel Program for Scientific Translations Limited, Jerusalem, 1964).

PETRov, O. M. 1963. The stratigraphy of the Quaternary deposits of the southern parts of the Chukotsk Peninsula. Bulletin of the Commission for the study of the Quaternary Period, No. 28. 135-52 pp.

PÉWÉ, T. L. 1955. Origin of the upland silt near Fairbanks, Alaska. Geological Society of America Bulletin, 66: 699-724.

1957. Permafrost and its effect on life in the North, in Arctic Biology. Corvallis: Oregon State College, 18th Annual Biological Colloquium. pp. 12-25.

1965. Fairbanks area. p. 6-36. Guidebook Field Conference F. Alaska, VIII International Congress of Quaternary Research (INQUA), Boulder.

PÉWÉ, T. L., D. L. HOPKINS, and J. L. GIDDINGS. 1965. The Quaternary geology and archeology of Alaska, in The Quaternary geology of the United States. H. E. Wright Jr. and D. G. Frey, editors. New Jersey: Princeton University Press. pp. 354-74.

PITELKa, F. A. 1957. Some characteristics of microtine cycles in the Arctic, in Arctic Biology. Corvallis: Oregon State College, 18th Annual Biological Colloquium. pp. 73-88.

PRUITT, w. O., JR. 1966. Ecology of terrestrial mammals, in Environment of the Cape Thompson region, Alaska. N. J. Wilimowski, editor; J. N. Wolfe, associate editor. Oak Ridge: United States Atomic Energy Commission. pp. 355-62.

QunY, w. B. 1951. Observations on mammals of the Seward Peninsula, Alaska. Journal of Mammalogy, 32: 88-99.

RaUSCH, R. L. 1951. Notes on the Nunamiut Eskimo and mammals of the Anaktuvuk Pass region, Brooks Range, Alaska. Arctic, 4: 147-195.

-_ 1953. On the status of some arctic mammals. Arctic, 6: 91-148.

1963. A review of the distribution of holarctic recent mammals; in Pacific Basin Biogeography, J. L. Gressitt, editor. Honolulu: Bishop Museum Press. pp. 29-43.

- 1964. The specific status of the narrow-skulled vole (Subgenus Stenocranius Kashchenko), in North America. Zeitschrift fur Saugetierkunde, 29: 343-358.

REPENNING, C. A., D. K. HOPKINS and M. RUBIN. 1964. Tundra rodents in a late Pleistocene fauna from the Tofty placer district, central Alaska. Arctic, 17:177-197.

SIDORowicz, J. 1960. Problems on the morphology and zoogeography of representatives of the genus Lemmus Lik 1795 from the Palarctic. Acta Theriologica, 4: 53-80.

THOMPSON, D. Q. 1955. Summer food preference of the brown and collared lemmings. Proceedings 2nd Alaskan Science Conference, pp. 166-176.

VANGENGEIM, E. A. 1961. Paleontologicheskoe obosnovanie stratigrafii anthropogenovykh otlozhenii severa Vostochnoe Sibiri; Trudy Geological Institute Akademia Nauk USSR, Moscow, No. $48.182 \mathrm{pp}$. 